\title{
Characterisation of the Draw Resistance Across a Lit Cigarette *
}

\author{
by Stéphane Colard ${ }^{1}$ and Rémi Julien ${ }^{2}$ \\ ${ }^{1}$ Imperial Tobacco Limited, Winterstoke Road, Bristol BS3 2LL, UK \\ ${ }^{2}$ SEITA, Imperial Tobacco Group, 48 rue Danton, 45404 Fleury-les-Aubrais, France
}

\section{SUMMARY}

The consumer senses and reacts to the draw resistance of the cigarette after it is lit. In spite of this obvious fact, this physical parameter is usually measured under standard conditions on the unlit cigarette (1). In order to evaluate more accurately the smokers' perception during the course of cigarette smoking, the theoretical aspects of the draw resistance measurement of a lit cigarette have been studied and an experimental device has been developed.

During puffing on a smoking machine, the variation of the pressure in the cigarette holder is influenced by several parameters which are independent of the characteristics of the cigarette itself, such as the airflow and the experimental device characteristics. Theory and experiments show that the saturation of the Cambridge filter pad and the dead volume, in the sample holder and connection tubes, significantly modify the measured pressure at the mouth end. The impact of these modifications can be minimized by the calculation of a single parameter which is characteristic of the draw resistance of the cigarette, and derived from the evolution of pressure over time. In addition, the integration of the measured pressure profile during each puff provides another way for the draw resistance assessment and gives a value related to the energy required to generate each of them.

An experimental device has been developed using a oneport smoking machine, a cigarette holder with a connection for a pressure sensor, an analog-to-digital converter and a recorder. For the calibration of the system, a procedure using multi-capillary pressure drop standards composed of capillary tubes is discussed.

Finally, the developed device and approach enabled the measurement and the recording of the draw resistance evolution over the time as the cigarette burns, and thus a better assessment of the potential smokers' sensation during smoking. [Beitr. Tabakforsch. Int. 25 (2013) 586-594]

\section{ZUSAMMENFASSUNG}

Der Verbraucher spürt und reagiert auf den Zugwiderstand der Zigarette, nachdem diese angezündet wurde. Trotz dieser offensichtlichen Tatsache wird dieser physikalische Parameter in der Regel jedoch unter Standardbedingungen an der nicht angezündeten Zigarette gemessen. Um die Wahrnehmung des Rauchers während des Rauchens exakter beurteilen zu können, wurden die theoretischen Aspekte der Zugwiderstandsmessung einer angezündeten Zigarette untersucht und eine Versuchsvorrichtung dafür entwickelt.

Beim Abrauchen einer Zigarette auf einer Rauchmaschine wird die Variation des Drucks im Zigarettenhalter von mehreren Parametern beeinflusst, die von den Eigenschaften der Zigarette selbst unabhängig sind, wie z. B. dem Luftstrom und den Eigenschaften der Versuchsvorrichtung. Die Theorie und die Versuche zeigen, dass die Sättigung des Cambridge-Filters und das Totvolumen im Probenhalter und den Verbindungsschläuchen den am Mundstück gemessenen Druck erheblich beeinflussen. Die Auswirkungen dieser Änderungen können durch die Berechnung eines einzigen Parameters minimiert werden, der für den Zugwiderstand der Zigarette charakteristisch ist und aus der Entwicklung des Drucks über die Zeit abgeleitet wird. Darüber hinaus bietet die Einbeziehung des während jedes Zugs gemessenen Druckprofils eine weitere Möglichkeit zur Beurteilung des Zugwiderstands und führt $\mathrm{zu}$ einem Wert für die Energie, die zur Erzeugung eines Zugs er- 
forderlich ist.

Unter Verwendung einer 1-Port-Rauchmaschine, eines Zigarettenhalters mit Drucksensor-Anschluss, eines Analog-Digital-Wandlers und eines Aufzeichnungsgeräts wurde eine Versuchsvorrichtung entwickelt. Für die Kalibrierung des Systems wird ein Verfahren mit multikapillaren Zugwiderstand-Standards bestehend aus Kapillarröhrchen erörtert.

Die entwickelte Vorrichtung und Herangehensweise ermöglichte die Messung und Aufzeichnung des Verlaufs des Zugwiderstands über die Zeit, während die Zigarette brennt, und somit eine bessere Beurteilung der potenziellen Wahrnehmung des Rauchers beim Rauchen. [Beitr. Tabakforsch. Int. 25 (2013) 586-594]

\section{RESUME}

La résistance au tirage d'une cigarette qui influence potentiellement le consommateur est perçue quand la cigarette est allumée, et non avant l'allumage. En dépit de cette évidence, ce paramètre physique est habituellement mesuré dans des conditions standards sur une cigarette éteinte (1). Dans le but d'évaluer plus précisément la perception du fumeur tout au long du fumage, les aspects théoriques liés à la mesure de la résistance au tirage durant le fumage ont été étudiés et un dispositif expérimental développé.

Au cours d'une bouffée sur machine à fumer, l'évolution de la pression dans le porte cigarette est influencée par plusieurs paramètres qui sont indépendants des paramètres propres de la cigarette, comme le niveau du débit d'aspiration et certaines caractéristiques du dispositif expérimental. Théorie et expérience montrent que le volume mort et la saturation du filtre Cambridge modifient significativement l'évolution de la pression à l'extrémité bouche. L'impact de ces modifications peut être minimisé par le calcul d'un seul paramètre, plus spécifiquement représentatif de la résistance au tirage d'une cigarette et déduit de l'évolution de la pression au cours du temps. Par ailleurs, un autre moyen d'évaluer la résistance au tirage consiste en l'intégration du profil de pression mesuré durant chaque bouffée, ce qui fournit une indication sur l'énergie requise pour produire chacune d'elles.

Un dispositif expérimental de mesure a été mis au point à partir d'une machine à fumée monocanal, un porte-cigarette auquel est connecté un capteur de pression, un convertisseur analogique/numérique et un enregistreur. Une procédure de calibrage de l'instrument utilisant une pige de tirage multi-capillaire calibrée selon des conditions standards est proposée.

Au final, le dispositif permet la mesure et l'enregistrement de l'évolution de la résistance au tirage en cours de fumage quand la cigarette se consume, et ainsi une meilleure évaluation de la perception potentielle du fumeur au cours du fumage. [Beitr. Tabakforsch. Int. 25 (2013) 586-594]

\section{INTRODUCTION}

One of the objectives of quality control is to make sure that the characteristics of the product conform to the consumers' expectations. The draw resistance of a cigarette is a key quality parameter measured under standard conditions on an unlit cigarette (1). However, the consumer reacts to the draw resistance when the cigarette is lit, not before lighting. Once lit, the cigarette coal creates an additional pressure drop at the burning extremity due to an increase of the temperature, causing an increase in the air viscosity inside the cigarette $(2,3)$. Consequently, for a given airflow, the draw resistance across a lit cigarette is higher than the draw resistance of the corresponding unlit cigarette, and can change along the cigarette as the tobacco rod burns. It is of interest to measure under standard laboratory conditions, a parameter directly linked to the ease of drawing of a puff during smoking for a better assessment of the smokers' sensorial perception. Investigations on the pressure drop of a burning cigarette have been conducted as the cigarette is smoked at a constant draw (4). In this paper, experimental and theoretical aspects of this measurement have been studied and are developed when a standard puff profile is applied.

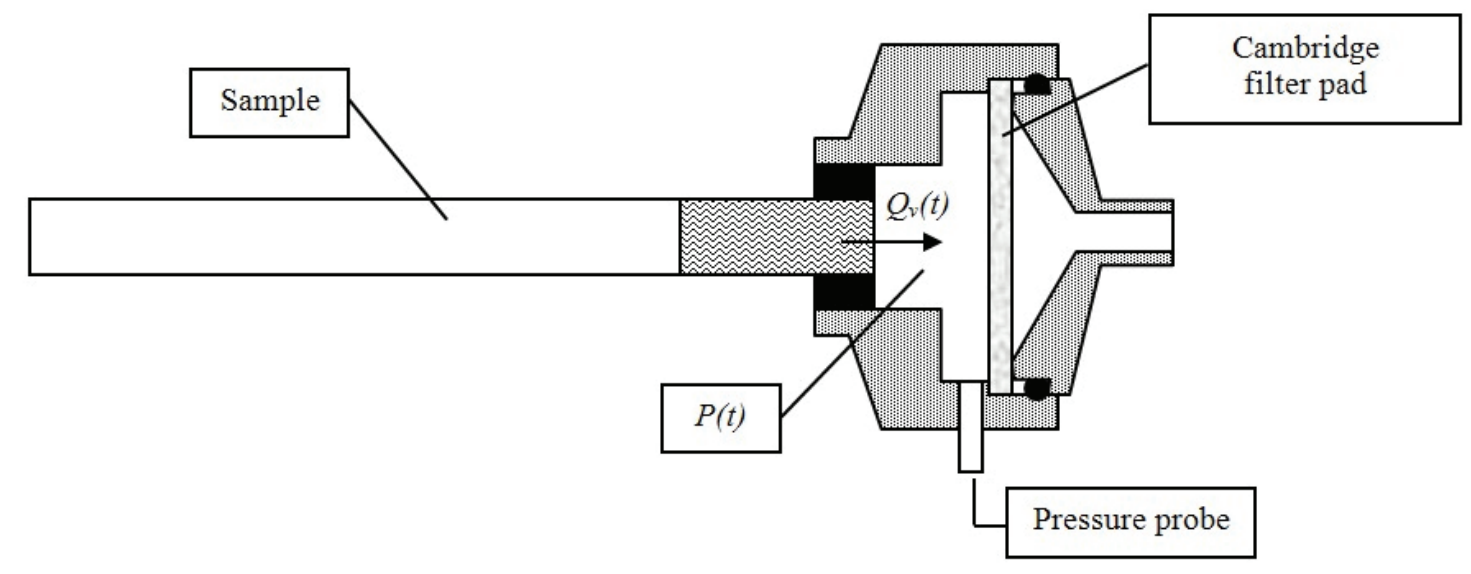

Figure 1. Sample holder and pressure probe 


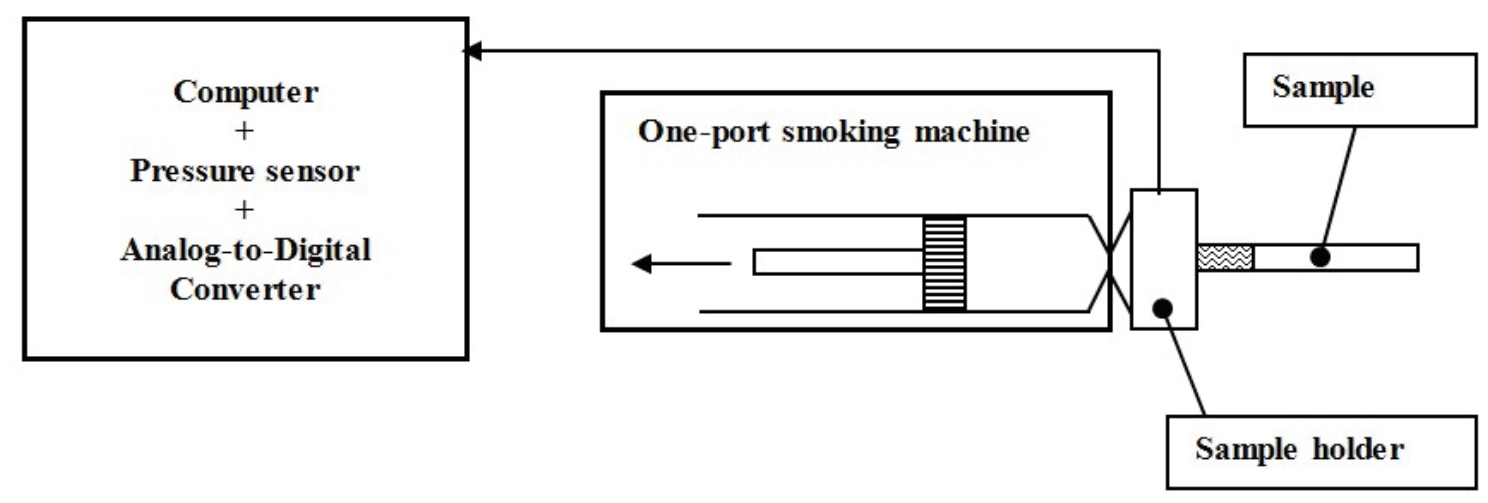

Figure 2. Experimental device

\section{EXPERIMENTAL SYSTEM}

An experimental device was developed on the basis of a one-port Borgwaldt smoking machine (RM1/G-R58 type, Borgwaldt KC, Germany). This machine comprised a syringe which could create a pressure difference, providing suction across the cigarette with a volumetric airflow at its mouth end. A sample holder containing a Cambridge filter pad of $44 \mathrm{~mm}$ diameter was connected to the syringe. The usual standardized puff parameters for smoking were used: a sinusoidal profile, a puff duration of $2.00 \pm 0.02 \mathrm{~s}$ every $60.0 \pm 0.5 \mathrm{~s}$ and a puff volume of $35.0 \pm 0.3 \mathrm{~mL}$ (5).

In order to obtain a tight connection between the sample and the smoking machine, a standardized holder with labyrinth seals such as defined in ISO 3308 was used (5). This sample holder, represented in Figure 1, was slightly modified for the measurement of the draw resistance. A link between the sample holder and the pressure sensor was made through a small orifice to allow measuring the pressure at the mouth end during smoking.

The system of pressure recording comprised a computer in which two processors developed by Sodim Instrumentation (Sodim, France) were installed: a processor including the pressure sensor and another one for the analog-to-digital conversion. A programme using a software distributed by Sodim allowed the data recording and the drawing of the pressure evolution with a time resolution of $55 \mathrm{~ms}$. Figure 2 shows the essential features of this system.

\section{MODEL}

\section{Gas transfer to the suction system}

The pressure difference imposed at a sample extremity during a puff generates airflow and then a transfer of gas from the atmosphere to the suction system. The relationship between volumetric airflow and pressure difference is linear with a multi-capillary standard (6). With a cigarette, the relationship between volumetric airflow and pressure difference is broadly linear in spite of some inertial effects occurring across the tobacco rod and the filter ventilation holes. The simulation of the draw resistance of a lit cigarette based on a model as published by DWYER et al. $(7,8)$ confirmed this hypothesis for both filter ventilated and non-filter ventilated products up to an airflow of $30 \mathrm{~mL} / \mathrm{s}$, as shown in Figure 3. Thus, it can be approximated, to the first order that the volumetric airflow $Q_{v}$ at a multi-capillary standard exit or a cigarette mouth end is simply proportional to the difference $\Delta P$ between the atmospheric pressure and the pressure at the standard extremity or cigarette mouth end.

$$
Q_{v}=k \times\left(P_{a t m}-P\right)=k \times \Delta P
$$

where

$Q_{v}=$ Volumetric airflow at the standard exit or cigarette mouth end

$P_{a t m}=$ Atmospheric pressure

$P=\quad$ Pressure at the standard extremity or cigarette mouth end

$k=$ Constant of proportionality.

The factor $k$ is related to the pressure drop; the higher the value, the lower is the difference of pressure for a given airflow.

A power rather than linear relationship could have provided an alternative mathematical model, but it is unnecessarily complex for the characterization of the draw resistance during smoking. Comparison between the experimental results and simulated values can show if the assumption of linearity is acceptable.

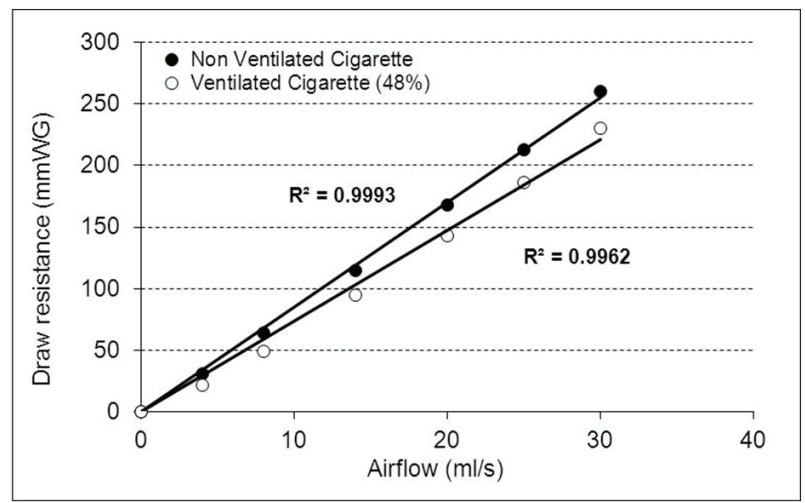

Figure 3. Simulation of the draw resistance of a lit cigarette versus the airflow 
The volumetric airflow across a multi-capillary standard or a cigarette is related to the number of moles $n$ which enter into the volume $V(t)$ behind the sample. $V(t)$ depends on the movement of the piston of the syringe as this movement has to consequently create an additional volume over time. The additional volume leads to a pressure difference compared to the atmospheric pressure inducing airflow across the sample. From the perfect gas law, the following differential equation can be derived:

$$
Q_{v}=\frac{d n}{d t} \times(\text { Molar Volume })=\frac{d n}{d t} \times \frac{R T}{P}
$$

where

$Q_{v}$ is expressed in $\mathrm{m}^{3} \cdot \mathrm{s}^{-1}$

$T=$ Gas temperature, expressed in $\mathrm{K}$

$P=$ Gas pressure, expressed in $\mathrm{Pa}$

$R=$ Universal gas constant $\left(8.314 \mathrm{~Pa} \cdot \mathrm{m}^{3} \cdot \mathrm{mol}^{-1} \cdot \mathrm{K}^{-1}\right)$.

The assumption that the perfect gas law applies to smoke is supported by two arguments. First, although the smoke is not a gas, but an aerosol, the particulate phase is less than $5 \%$ of the smoke by mass (9). In terms of volume this percentage is significantly lower. The volume of the particulate phase can then be reasonably neglected. This assumption is often made in the case of analysis of gas phase constituents, for example, the determination of carbon monoxide concentration in smoke (10). Second, the pressure remains close to the atmospheric pressure.

By combining equations [1] and [2], the factor $k$ which is characteristic of the pressure drop can be linked to the evolution of the molar flow into the holder and the changes in the pressure.

$$
\frac{d n}{d t}=\frac{1}{R T} \times k \times P \times \Delta P
$$

In the sample holder and the syringe, the change of $n$ over time can be linked to the change of pressure, volume and temperature by the perfect gas law.

$$
\frac{d n}{d t}=\frac{1}{R T} \times \frac{d(P V)}{d t}-\frac{P V}{R T^{2}} \times \frac{d T}{d t}
$$

where

$V=$ Volume of the sample holder and syringe at the time $t$.

By combining equations [3] and [4] through the equalization of the derivative of $n$, an equation associating pressure, volume, temperature, time and $k$ can be derived.

$$
k \times P \times \Delta P=\frac{d(P V)}{d t}-\frac{P V}{T} \times \frac{d T}{d t}
$$

By developing the derivative of $P \times V$, noting that $\Delta P=\left(P_{a t m}-P\right)$ and assuming $P_{\text {atm }}$ is constant during a puff, the following differential equation can be obtained:

$$
\frac{d \Delta P}{d t}=\frac{\left(P_{a t m}-\Delta P\right)}{V} \times\left[\frac{d V}{d t}-k \times \Delta P-\frac{V}{T} \times \frac{d T}{d t}\right]
$$

In equation [6] the choice was made to express $\Delta P$ rather than $P$ because $\Delta P$ corresponds to the measured parameter. The mathematical modelling of the change of pressure during a puff should allow the derivation of parameters from the pressure profile which are specifically characteristic of the draw resistance during smoking, for example, the factor $k$. The use of the equation [6] for calculating $\Delta P$ over time requires the knowledge of the volume $V(t), d V / d t$ and the temperature change $T(t)$ and $d T / d t$ during the puff. Two steps need to be considered: First, the movement of the piston generating a puff of certain shape, and second, the pressure equalization with the atmosphere when the piston stops.

\section{First suction step: Start of the piston movement}

Any puff profile is applicable to the differential equation [6] if the piston movement over time is known. Subject to certain mathematical requirements, equation [6] provides a unique solution $\Delta P(t)$ for any puff profile $V(t)$. However, a sinusoidal profile has the advantage of being easy to produce from a rotational movement, to correspond to international smoking standards, and to be mathematically expressed in a simple form. Following the International Standard (5) a piston can be used in order to create a volume change over time with a sinusoidal profile such as:

$$
\frac{d V}{d t}=\operatorname{Max}\left[\frac{d V}{d t}\right] \times \sin \left(\frac{\pi}{T_{d}} \times t\right)
$$

where

$\operatorname{Max}[d V / d t]=$ Maximum rate of volume change

$T_{d}=$ Duration of the piston displacement.

It is important to note that $d V / d t$ is not the airflow across the sample. Indeed, $d V / d t$ is related to the creation of a volume as the piston is moving and exists even if the sample is blocked. The volume created $V_{c}(t)$ is the integral of $d V / d t$ from 0 to $t$ :

$$
V_{c}(t)=\frac{T_{d}}{\pi} \times \operatorname{Max}\left[\frac{d V}{d t}\right] \times\left[1-\cos \left(\frac{\pi}{T_{d}} \times t\right)\right]
$$

Considering the time $t=T_{d}$ when the final volume created by the piston $V_{c}\left(T_{d}\right)$ is reached, the value of the maximum rate of volume change is given by

$$
\operatorname{Max}\left[\frac{d V}{d t}\right]=\frac{\pi \times V_{c}\left(T_{d}\right)}{2 \times T_{d}}
$$

$V_{c}\left(T_{d}\right)$ is closely related to the puff volume as this represents the volume created behind the cigarette during complete piston displacement.

Other volumes have to be taken into account, like those of the sample holder and connection tubes. The volume behind the cigarette is the sum of an initial dead volume and the volume created by the piston movement. Equation [8] 
becomes

$$
V(t)=V_{\text {dead }}+\frac{V_{c}\left(T_{d}\right)}{2} \times\left[1-\cos \left(\frac{\pi}{T_{d}} \times t\right)\right]
$$

where

$V_{\text {dead }}=$ Dead volume.

The differential equation [6] can be solved easily by a numerical method. Assuming

$$
\frac{d \Delta P}{d t} \approx \frac{\Delta P_{i}-\Delta P_{i-1}}{\Delta t}
$$

which is valid considering the gradual change of the pressure for a sinusoidal puff profile, equation [6] becomes

$$
\begin{aligned}
& \frac{k \Delta t}{V} \times \Delta P_{i}^{2}-\left[1+\frac{\Delta t}{V} \times\left(\frac{d V}{d t}+k P_{a t m}-\frac{V}{T} \times \frac{d T}{d t}\right)\right] \times \\
& \Delta P_{i}+\left(\frac{P_{a t m} \Delta t}{V} \times \frac{d V}{d t}-\frac{P_{a t m} \Delta t}{T} \times \frac{d T}{d t}+\Delta P_{i=1}\right)=0
\end{aligned}
$$

where

$V=$ Volume of the sample holder and syringe, expressed in $\mathrm{mL}$

$P=$ Pressure at the cigarette mouth end, expressed in $\mathrm{mmWG}^{1}$

$P_{a t m}=$ Atmospheric pressure, expressed in $\mathrm{mmWG}$

$\Delta P_{i}=$ Pressure difference, expressed in $\mathrm{mmWG}$

$T=$ Gas temperature, expressed in $\mathrm{K}$

$\Delta t=$ Pressure sampling period, expressed in $\mathrm{s}$

$k=$ Constant of proportionality, expressed in $\mathrm{mL} \cdot \mathrm{s}^{-1} \cdot \mathrm{mmWG}^{-1}$.

The initial condition, i.e. at $i=1, \Delta P_{\mathrm{i}-1}=\Delta P_{0}=0$, starts the process of the calculation of $\Delta P_{1}$ and each consecutive $\Delta P_{\mathrm{i}}$ over time. Therefore, the change of the pressure at the cigarette mouth end during the period of time the piston of the syringe is moving can be calculated.

$V(t)$ is given by equation [10], $d V / d t$ by equation [7], but $T(t)$ and $d T / d t$ need to be measured or estimated. Although the change of the temperature can be neglected when the pressure drop is measured on a multi-capillary standard, the potential change cannot be ignored when a cigarette is smoked. During a puff, the coal temperature can reach up to $900{ }^{\circ} \mathrm{C}(2)$. Even if a rapid decrease occurs across the rod, a progressive increase of the temperature on a series of puffs is likely to be observed at the cigarette mouth end. As simulated in Figure 4, a temperature increase in the sample holder during the course of the puff reduces the pressure difference due to the gas volume expansion. The maximum of pressure difference is reduced by $1.8 \%$ for linear increase of $5{ }^{\circ} \mathrm{C}$ in $2 \mathrm{~s}$, and by $3.7 \%$ for linear increase of $10{ }^{\circ} \mathrm{C}$. Temperatures in cigarette filters during smoking have been investigated and discussed previously $(11,12)$. A lesser increase was observed in the last puffs

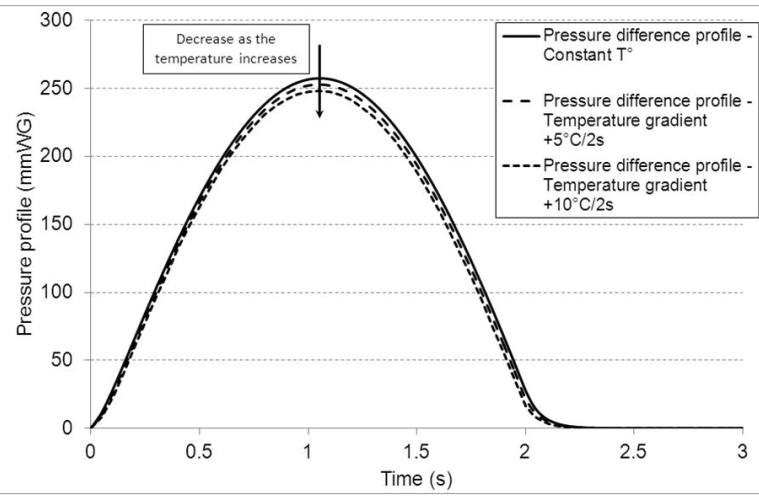

Figure 4. Effect of the temperature change in the sample holder during the puff on the profile of pressure difference

when the ISO regime was applied compared with more intense regimes. Figure 5 represents the evolution of the temperature in the Cambridge filter pad when 5 cigarettes were smoked consecutively with the ISO regime. Two King Size products were tested: one non-ventilated and one ventilated with a filter ventilation of $52 \%$. For the nonventilated product, a temperature increase was confirmed. The level increased up to $6{ }^{\circ} \mathrm{C}$ with a maximum change rate of $4{ }^{\circ} \mathrm{C}$ per minute. However, no peak of temperature was observed during the puffs. The slow and progressive heating of the holder associated with its thermal inertia makes a significant change of the temperature unlikely during the two seconds course of a puff. For the ventilated product, no temperature change was observed. This is explained by the entry of air at ambient temperature via the filter ventilation holes. Consequently, it seemed reasonable to assume that no significant temperature change occurred during a puff when the ISO regime was applied, i.e. $d T / d t=0$.

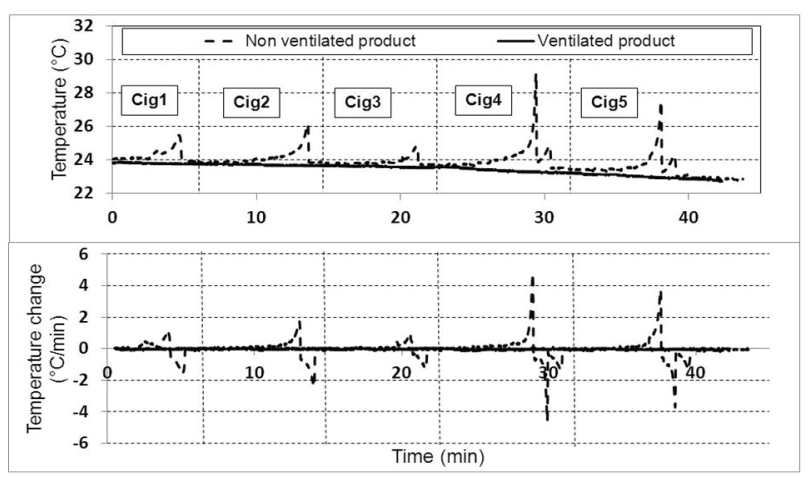

Figure 5. Temperature change in the sample holder when 5 cigarettes are consecutively smoked under the ISO regime (dot line: non-filter ventilated product, continuous line: filter ventilated product $52 \%$ )

\section{Second suction step: End of the piston movement}

When the piston stops moving, the pressure behind the sample inside the holder is still below ambient pressure. $\Delta P=\Delta P\left(T_{d}\right) ; d V / d t=0 ; V=V\left(T_{d}\right)=V_{\text {dead }}+V_{c}\left(T_{d}\right)$.

\footnotetext{
${ }^{1}$ For a cigarette or a multi-capillary pressure drop standard, pressures are conventionally expressed in millimetre of water gauge (mmWG). This unit has then been preferred to the Pascal $(1 \mathrm{mmWG}=9.81 \mathrm{~Pa})$.
} 
Assuming that the mean temperature during this short phase remains unchanged as discussed before, equation [6] becomes

$$
\frac{d \Delta P}{d t}+\frac{k \times P_{a t m}}{V} \times \Delta P-\frac{k}{V} \times \Delta P^{2}=0
$$

and the analytical solution is:

$$
\frac{\Delta P(t)=}{\left(P_{a t m}-\Delta P\left(T_{d}\right)\right) \times \exp \left[\frac{k \times P_{a t m}}{V} \times\left(t-T_{d}\right)\right]+\Delta P\left(T_{d}\right)}
$$

From equation [12], we can calculate the change of the pressure during the phase of pressure equalization, after the piston stopped.

\section{Draw resistance assessment}

For the standardized measurement of the draw resistance of multi-capillary standards or unlit cigarettes, a constant volumetric airflow of $17.5 \mathrm{~mL} / \mathrm{s}$ is sucked across the cigarette (1). It is not the case for the draw resistance measurement during smoking for which the puff profile is sinusoidal - see equation [7]. The parameter $k$ defined previously by equation [1] characterizes the sample, and is directly linked to the relationship between draw resistance and airflow. Consequently, it is interesting to deduce the value of $k$ from the measurement of the pressure profile.

By considering that $d T / d t=0$ and the time $t=t_{\max }$ at which $\Delta P(t)=\Delta P_{\max }$ and $d \Delta P / d t=0$, equation [6] becomes

$$
\left.\frac{d V}{d t}\right|_{t=t \max }=k \times \Delta P_{\max }
$$

from which $k$ can be deduced independently of the dead volume $V_{\text {dead }}$.

$$
k=\frac{\pi \times V_{c}\left(T_{d}\right)}{2 \times T_{d} \times \Delta P_{\max }} \times \sin \left(\frac{\pi}{T_{d}} \times t_{\max }\right)
$$

Knowing the value of the parameter $k$, an equivalent draw resistance with airflow of $17.5 \mathrm{~mL} / \mathrm{s}, \Delta P_{\text {equi }}$, can be derived from equation [1] giving the volumetric airflow at the cigarette mouth end.

$$
\Delta P_{\text {equi }}=\frac{17.5}{k}=\frac{35 \times T_{d} \times \Delta P_{\max }}{\pi \times V_{c}\left(T_{d}\right) \times \sin \left(\frac{\pi}{T_{d}} \times t_{\max }\right)}
$$

where

$\Delta P_{\text {equi }}=$ Equivalent draw resistance at an airflow of $17.5 \mathrm{~mL} / \mathrm{s}$, expressed in $\mathrm{mmWG}$.

The pressure profile area $A$, as defined by equation [15], also offers a solution for assessing the draw resistance.

$$
A=\int_{0}^{t_{\text {end }}} \Delta P . d t
$$

where

$t_{\text {end }}=$ Time when the change of $\Delta P$ ceased, expressed in $\mathrm{s}$ $A=$ Pressure profile area, expressed in mmWG.s.

The area $A$ can be associated to the energy necessary to generate the puff. The factor $k$ can be estimated from equation [1] and [15]; for a puff volume of $35 \mathrm{~mL}$,

$$
k=\frac{\int_{0}^{t_{\text {end }}} Q_{v} \cdot d t}{A} \approx \frac{35}{A}
$$

An equivalent draw resistance with airflow of $17.5 \mathrm{~mL} / \mathrm{s}$ can then be deduced from equations [14] and [16].

$$
\Delta P_{\text {equi }} \approx \frac{A}{2}
$$

\section{RESULTS}

\section{Comparison of the model to the measurements}

The pressure measured with the experimental device described previously during cigarette smoking under ISO 3308 conditions is illustrated in Figure 6. Draw resistance during smoking has been assessed with a King Size cigarette of $84 \mathrm{~mm}$ length; $21 \mathrm{~mm}$ filter length; a draw resistance cigarette unlit of $130 \mathrm{mmWG}$; a diameter of $7.9 \mathrm{~mm}$ and no filter ventilation. The time between puffs when the pressure is constant has been removed from Figure 6. The sinusoidal profile of the pressure related to the sinusoidal profile of the puff is observed, with a clear puff-to-puff change as the cigarette burns.

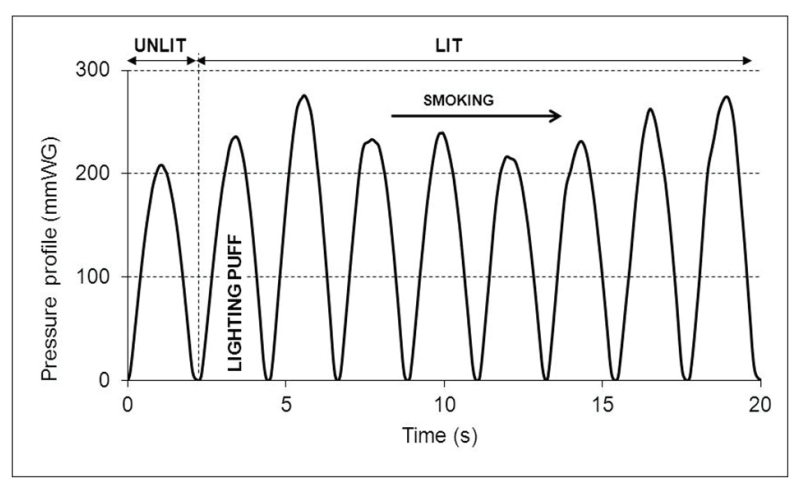

Figure 6. Measurement of the pressure in the sample holder during smoking (time between puffs excluded)

In order to compare experimental data and simulation results, measurements were carried out with a multi-capillary pressure drop standard of $391 \mathrm{mmWG}$, which corresponds to the middle of the typical range of such standards, and with a lit cigarette. For the multi-capillary pressure drop standard, the pressure drop being known, the factor $k$ was calculated from the equation [14] to $k=4.48 \times$ 
$10^{-2} \mathrm{~mL} \cdot \mathrm{s}^{-1} \cdot \mathrm{mmWG}^{-1}$. The equivalent draw resistance being unknown for the lit cigarette, the factor $k$ was adjusted to fit to the measured pressure profile assuming the temperature of the gas in the Cambridge filter pad and syringe was constant during the puff duration. A value of $k=1.06 \times 10^{-1} \mathrm{~mL} \cdot \mathrm{s}^{-1} . \mathrm{mmWG}^{-1}$ was obtained, which corresponds to an equivalent draw resistance of $165 \mathrm{mmWG}$. As shown in Figure 7, a good fit over time was possible; the relative difference between simulated and measured maximum pressures is less than $2 \%$. This result shows that the assumption of linearity made in equation [1] for multicapillary pressure drop standards also applies to lit cigarettes.

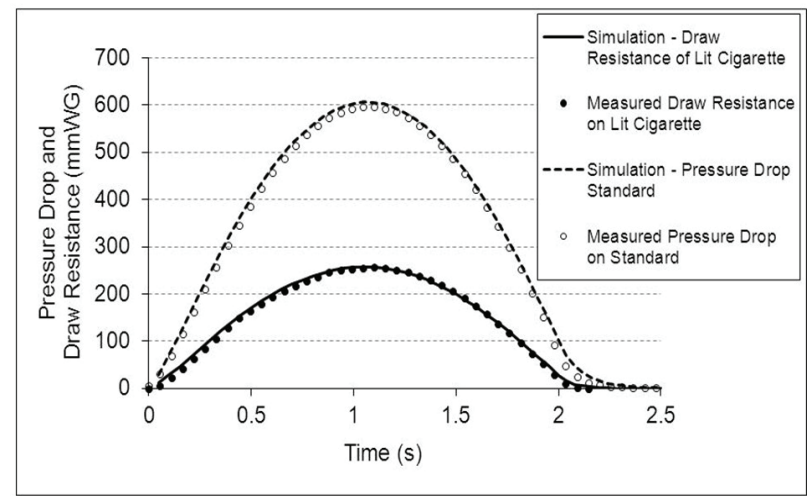

Figure 7. Comparison of the pressure drop measured and calculated for a lit cigarette and a multi-capillary pressure drop standard

\section{Repeatability of the measurement}

The repeatability of the pressure drop measurement cannot be estimated with a lit cigarette, which is continuously modified by the burning process. However, the multi-capillary pressure drop standards offer the required stability to conduct such a study (6). Consequently, the previously used multi-capillary pressure drop standard of $391 \mathrm{mmWG}$ for the validation of the model was tested for this estimation of repeatability. Figure 8 shows the superimposition of ten pressure profiles measured under repeatability conditions. The coefficient of variation of the maximum pressure is less than $0.3 \%$.

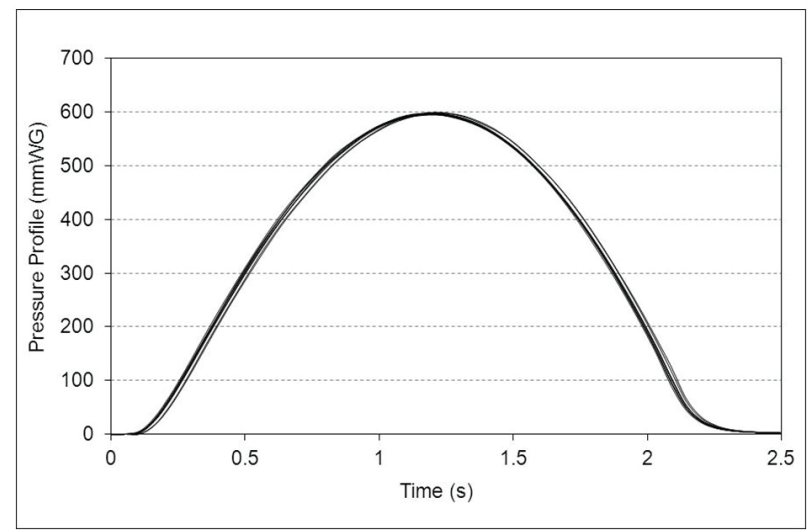

Figure 8. Superimposition of 10 pressure profiles measured with a multi-capillary pressure drop standard of $391 \mathrm{mmWG}$
The level of repeatability and the possibility to compare simulated and measured values offer the option to use calibrated multi-capillary pressure drop standards for the check and the calibration of the system on a periodical basis.

\section{Effect of the dead volume}

Figure 9 represents the solutions of equation [6] for two dead volumes of 0 and $200 \mathrm{~mL}$ respectively, and $T_{d}=2 \mathrm{~s}$, $V_{c}\left(T_{d}\right)=35 \mathrm{~mL}, k=0.175 \mathrm{~mL} \cdot \mathrm{s}^{-1} \cdot \mathrm{mmWG}^{-1}, \Delta t=0.05 \mathrm{~s}$.

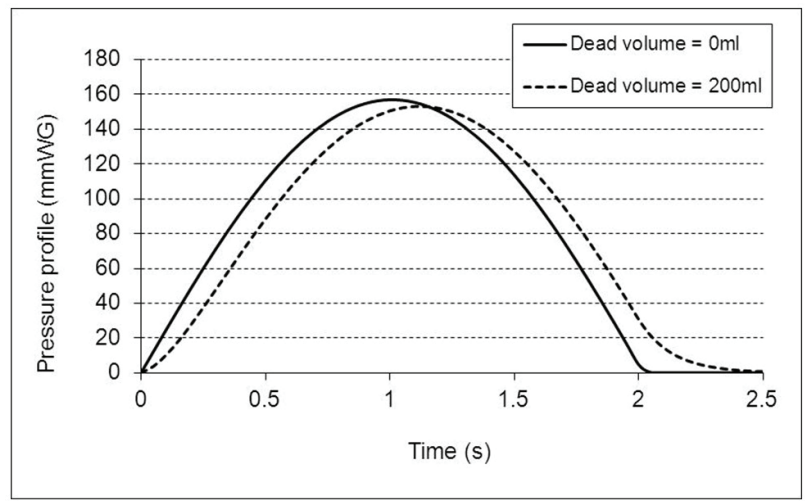

Figure 9. Calculation of the effect of the dead volume ( 0 and $200 \mathrm{~mL}$ ) on the pressure profile

It appears that the dead volume induces an inflexion point at the beginning of the puff, a decrease of the maximum pressure difference and a shift of the profile. These observations are in agreement with previous studies and alternative modelling approaches (13).

For a dead volume varying from 0 to $40 \mathrm{~mL}$ which is the typical range with the RM1/G-R58 type smoking machine, the area of the pressure profile and the maximum value $\Delta P_{\max }$ have been calculated. Results represented in Figure 10 show that the area is significantly less sensitive to the dead volume than the maximum pressure. In addition, the integration has the advantage to smooth the variations of the individual measurements.

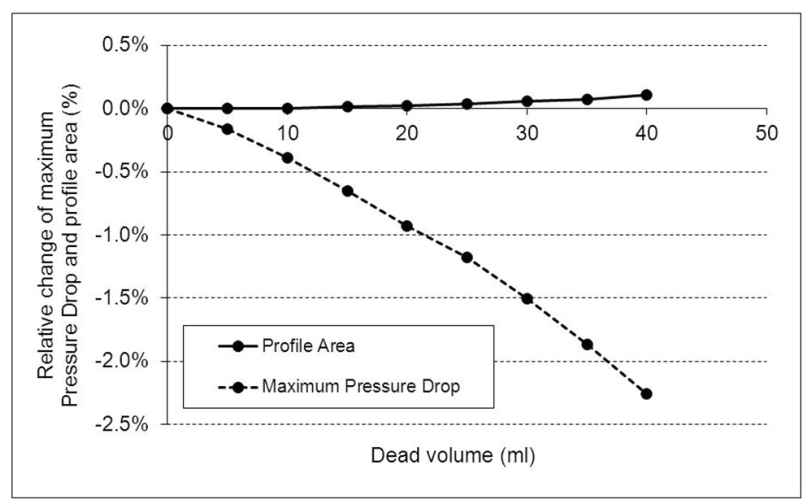

Figure 10. Change of the profile area and maximum pressure drop versus dead volume 


\section{Effect of the Cambridge filter pad}

Before measuring the draw resistance, a Cambridge filter pad was inserted in the sample holder in order, at least, to protect the smoking machine mechanism. During smoking, the saturation by particulate matter of the filter induces an increasing additional pressure drop in the sample holder. When too high, this pressure drop can significantly modify the airflow across the filter pad and therefore the shape of the puff profile. Experiments showed that the effect of this pressure drop can be discounted when the filter is clean. Figure 7 shows indeed that predicted and measured pressure profiles on a multi-capillary standard fit well when the Cambridge filter pad is clean. However, the effect could become increasingly relevant and even significant with increasing number of puffs across a lit cigarette. This effect has been estimated by alternating measurement of lit cigarettes with a nominal ISO tar yield of $10 \mathrm{mg}$ and a multi-capillary pressure drop standard carefully kept at constant temperature. As shown in Figure 11, the maximum of the pressure profile decreased by about $1 \%$ after 40 puffs. Experimental variability explains why the maximum pressure difference is sometimes higher than the first puff value. It was then recommended to change the Cambridge filter pad regularly when the measurements were carried out with lit cigarettes, typically after a maximum of 5 cigarettes were smoked with the ISO regime (5).

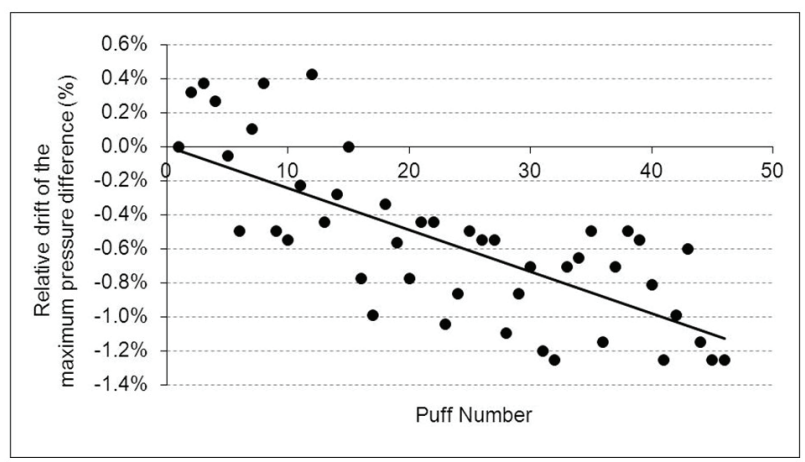

Figure 11. Relative drift from the first measurement of the maximum pressure difference over a puff drawn on a multicapillary standard through a Cambridge filter pad. A variable number of puffs from a lit cigarette has been drawn through the pad before measurement of the pressure drop standard.

\section{Cigarette draw resistance assessment}

As demonstrated in the model section, an equivalent draw resistance can be calculated after the determination of $\Delta P_{\max }$ and $t_{\max }$ for each profile by equations [13] and [14]. It has been identified that the pressure profile area was also an interesting parameter from which an equivalent draw resistance could be derived with the equation [17]. This area is linked to the energy necessary to generate a puff, which then characterizes the draw resistance during smoking. In addition, this area presents lower sensitivity to the dead volume as shown on Figure 10, and to experimental noise than the maximum pressure difference due the integration effect. Figure 12 illustrates the three parameters which can be used to characterize the draw resistance of the tested cigarette during smoking from the treatment of the data represented on Figure 6:

1. The maximum pressure drop

2. The pressure profile area

3. The equivalent draw resistance

a. deduced from the maximum pressure drop

b. or deduced from the pressure profile area

The first point of each curve corresponds to the unlit cigarette. After lighting, an increase of draw resistance for the two first puffs is observed probably linked to the formation of the coal, followed by a decrease until the middle of the tobacco rod as the cigarette length decreases. Finally, the draw resistance increases once again, probably due to an effect of the gas temperature increase across the cigarette as a consequence of the reduction of the cigarette paper ventilation (14).

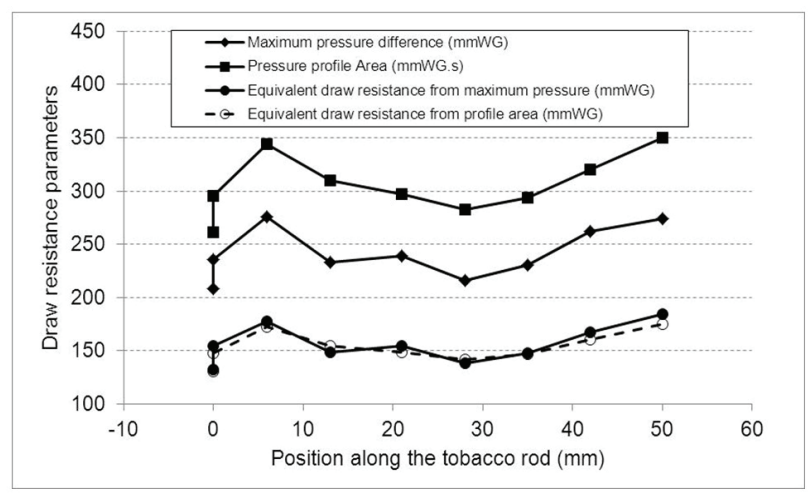

Figure 12. Draw resistance of a cigarette during smoking

\section{CONCLUSIONS}

An experimental device capable of measuring and recording the draw resistance during smoking has been developed using a one-port smoking machine, a modified cigarette holder for the pressure measurement, and two processors inserted in a computer (pressure sensor and analog-todigital converter). To ensure experimental performance, this device can be readily calibrated using multi-capillary pressure drop standards.

Theoretical aspects were explored and experimental studies were carried out to set up a methodology for the draw resistance measurement during smoking. These studies underlined some important parameters influencing the draw resistance measurement during smoking, such as the dead volume behind the sample and the saturation of the Cambridge filter. Three parameters characterizing the draw resistance across a lit cigarette have been proposed: First, an equivalent draw resistance with an airflow of $17.5 \mathrm{~mL} / \mathrm{s}$, second, the pressure profile area related to energy required to generate a puff and third, the maximum pressure. As expected, an increase of the draw resistance was observed once the cigarette was lit due to the contribution from coal formation to overall pressure drop, as well as a change of the draw resistance as the tobacco rod burns. Compared with the standard protocol of draw resistance measurement (1), the proposed methodology pro- 
vides a characterisation of the sensory perception felt when the cigarette is lit.

The theoretical aspects developed in this paper could also be of interest for modelling the consequences on puff profiles and pressures in the sample holder under more intense mechanical smoking regimes. In that case, considerations on the possible significant increase of the temperature in the sample holder will have to be made as this increase might alter the product characterisation.

\section{REFERENCES}

1. International Organisation for Standardisation (ISO): International Standard ISO 6565:2011. Tobacco and tobacco products. Draw resistance of cigarettes and pressure drop of filter rods. Standard conditions and measurement; ISO, Geneva, Switzerland, 2011.

2. Saidi, M.S., A. Mhaisekar, M.R. Hajaligol, and M. Subbiah.: Mathematical Modeling of a Lit-End Cigarette: Puffing Cycle and Effects of Puff Counts; Beitr. Tabakforsch. Int. 23 (2008) 46-62.

3. Eitzinger, B. and S. Pirker: Numerical Simulation of a Cigarette during Smoking; Beitr. Tabakforsch. Int. 21 (2005) 402-416.

4. Baker, R.R.: Contributions to the Draw Resistance of a Burning Cigarette; Beitr. Tabakforsch. 8 (1975) 124-132.

5. International Organisation for Standardisation (ISO): International Standard ISO 3308:2012. Routine analytical smoking machine - Definition and standard conditions; ISO, Geneva, Switzerland, 2012.

6. Keith, C.H. and J.A. Corbin: Multiple Capillary Pressure Drop Standards; Beitr. Tabakforsch. 8 (1975) 60-64.

7. Dwyer, R.W. and P. Chen: Prediction of Pressure Drop and Ventilation in a Lit Cigarette; Beitr. Tabakforsch. Int. 18 (1999) 205-211.

8. Dwyer, R.W., P. Chen, and R.D. Wasyk: A Mathematical Scheme for Calculating Flows and Pressure Drops in Lit and Unlit Cigarettes; Beitr. Tabakforsch. Int. 19 (2001) 189-203.
9. Perfetti, T.A. and A. Rodgman: The Complexity of Tobacco and Tobacco Smoke; Beitr. Tabakforsch. Int. 24 (2011) 215-232.

10. International Organisation for Standardisation (ISO): International Standard ISO 8454:2007. Cigarettes Determination of carbon monoxide in the vapour phase of cigarette smoke - NDIR method; ISO, Geneva, Switzerland, 2007.

11. Purkis, S.W., C. Mueller, M. Intorp, and H. Seidel: The Influence of Cigarette Designs and Smoking Regimes on Vapour Phase Yields; Beitr. Tabakforsch. Int. 24 (2010) 33-46.

12. Purkis, S.W., X. Cahours, M. Rey, B. Teillet, V. Troude, and T. Verron: Some consequences of using cigarette smoking regimes with different intensities on smoke yields and their variability; Regul. Toxicol. Pharmacol. 59 (2011) 293-309.

13. Gaisser, H.: Fluiddynamik in der Cigarette und deren Einfluß auf den Zugwiderstand [Fluid Dynamics in the Cigarette and its Influence on Pressure Drop]; Beitr. Tabakforsch. Int. 16 (1994) 11-46.

14. Purkis, S.W., V. Troude, G. Duputié, and C. Tessier: Limitations in the characterisation of cigarette products using different machine smoking regimes; Regul. Toxicol. Pharmacol. 58 (2010) 501-515.

Corresponding author:

Stéphane Colard

Imperial Tobacco Limited

Winterstoke Road

Bristol BS3 2LL, UK

E-mail: stephane.colard@fr.imptob.com 